Prace Komisji Geografii Komunikacji PTG

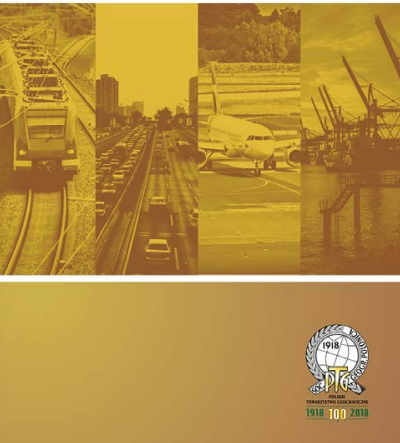

\section{Transport Geography Papers of Polish Geographical Society}

2018, 21(4), 44-59

DOI 10.4467/2543859XPKG.18.023.10781
Received: 30.09 .2018

Received in revised form: 14.12 .2018

Accepted: 15.12 .2018

Published: 31.12 .2018

\title{
TRENDS IN THE DEVELOPMENT OF TROLLEYBUS TRANSPORT IN POLAND AT THE END OF THE SECOND DECADE OF THE 21ST CENTURY
}

\author{
Trendy rozwojowe transportu trolejbusowego w Polsce pod koniec drugiej dekady \\ XXI wieku
}

\section{Marcin Połom}

Department of Regional Development Geography, Institute of Geography, Faculty of Oceanography and Geography, University of Gdańsk, Bażyńskiego 4 st., 80-309 Gdańsk, Poland

e-mail: marcin.polom@ug.edu.pl

\section{Citation:}

Połom M., 2018, Trends in the development of trolleybus transport in Poland at the end of the second decade of the 21st century, Prace Komisji Geografii Komunikacji PTG, 21(4), 44-59.

Abstract: Trolleybus transport played a changing role in Poland. Historically, these were both periods of dynamic development and rapid regression. The article analyzes the period from 2004 to 2018. An attempt was made to systematize and organize information on the development of trolleybus transport in this period. The available scientific literature as well as the economic, organizational and technological conditions for the functioning of trolleybus transport were analyzed. The analyzed period was undoubtedly a time of dynamic development of all three existing trolleybus systems in Poland. The structural funds of the European Union played a significant role in this, allowing to revitalize neglected and underinvested systems. At the same time, climate change has influenced global and local conditions in terms of the approach to transport in cities. Trolleybuses perfectly respond to the demands to reduce emissions from transport in cities. Also thanks to the development of battery technologies, trolleybuses have become more flexible in operation. The article compares the years 2004 and 2018, additionally illustrating the changes taking place on the maps.

Key words: trolleybus transport, electrobility, sustainable transport, urban transport development 


\section{Introduction}

In the last decade, trolleybus transport has undergone a significant transformation and, at the same time, a major change in its perception. Some urban transport researchers believed that there was no future for trolleybuses, because vehicles dependent on the overhead catenary were inflexible in terms of movement and costly to maintain. Two factors helped trolleybuses losing economic calculations. The first one concerns the dynamic development of battery technology, in particular increasing their capacity, while reducing the size and, above all, weight. The second factor is related to the introduction of increasingly restrictive policies in the field of climate protection. Negative climate change in the last decade has accelerated, and with it the European Union and other developed countries are tightening transport policies by favoring zero-emission vehicles (Połom, 2015b; Rasiński, 2018).

In Poland, trolleybus transport enjoyed variable popularity. After World War II, it allowed to rebuild passenger transport in many cities. Then it was displaced by diesel buses, which began to be produced domestically. During this period, trolleybuses were imported, first from France and then from Germany and Czechoslovakia. In the 1970s and 1980s, attention was paid to trolleybuses again due to the liquid fuel crisis. At that time, it was planned to create many new trolleybus systems, but the implementation of these plans was opposed by the general economic crisis in Poland. The political transformation at the turn of the 1980s and 1990s brought many changes also in transport. Public transport shifted from central financing to local governments, which contributed to the regression of expensive electric transport systems, i.e. trams and trolleybuses. During this period, trolleybuses in Dębica (1992), Warsaw (1995) and Słupsk (1999) were abolished. The remaining three trolleybus networks (Gdynia with Sopot, Lublin and Tychy) survived the difficult period and although decommissioning was considered in all three cases, the plan was not implemented for various reasons (Połom, 2015b).

The beginning of the 21st century is a completely different reality. Poland's accession to the European Union made it possible first to use pre-accession funds, and then structural funds, and slowly rebuild underinvested trolleybus systems, and then modernize and develop them. Since 2004, trolleybus net- works in Gdynia with Sopot, Lublin and Tychy have undergone a huge transformation, becoming even exemplary in Europe. Many model solutions were developed in these three trolleybus networks, which were then used by other European cities.

The article is both organizing and comparative. It presents all the most important activities undertaken in the field of trolleybus transport in Poland in the period 2004-2018. In the second part of the study, the condition of trolleybus transport in three cities for 2004 and 2018 was compared. The research assumption of the article was to verify the claim that trolleybus transport in Poland has survived and is developing thanks to the aid of the European Union, and the achievements in the field of technological solutions are a model that they use other carriers and local governments in Europe.

The study used literature sources and statistics published by the Economic Chamber of Public Transport (Izba Gospodarcza Komunikacji Miejskiej - IGKM), as well as unpublished materials of trolleybus companies and transport authorities from Gdynia, Lublin and Tychy. Based on the dispersed sources, original drawings were prepared, which illustrate the spatial development and infrastructure investments made in the period 2004-2018.

\section{Scientific background}

In the scientific literature the subject of trolleybus transport is still relatively rare. Despite the fact that trolleybuses perfectly respond to the postulates of transport policies from the local to the national level in terms of reducing the impact of transport on the environment. In recent years, mainly issues related to technical aspects have been addressed. There are no studies comparing trolleybus transport with other means of urban transport and analyzes related to the actual impact of trolleybuses on the state of the environment in cities, taking into account various sources of electricity (e.g. in Poland from fossil fuels). Although urban transport remains an important element of research in the field of transport economics, there are few scientific papers devoted to the economic accounting of trolleybuses, especially in relation to other modes of urban transport. Since the beginning of the 21st century, several dozen works have been written on various aspects of the functioning of trolleybus transport in Poland and in the world, which have been collected and presented in tab. 1. 
Tab. 1. Review of the scientific literature on trolleybus transport in Poland and in the world.

\begin{tabular}{|c|c|c|}
\hline \multicolumn{2}{|c|}{ Described aspects: } & Sources: \\
\hline \multirow{3}{*}{ Economic efficiency } & $\begin{array}{l}\text { economic comparison } \\
\text { with other means of public } \\
\text { transport }\end{array}$ & $\begin{array}{l}\text { Bartłomiejczyk et al., 2012; Klucininkas, Matulevicius, 2009; Kühne, } \\
\text { 2010, Połom, 2015b; Wołek, Wyszomirski, } 2013\end{array}$ \\
\hline & $\begin{array}{l}\text { economic efficiency of } \\
\text { trolleybus transport }\end{array}$ & $\begin{array}{l}\text { Bartłomiejczyk, Mirchevski, 2014; Grzelec, Wyszomirski, 2010; Falvo, } \\
\text { 2012; Hebel, 2014; Jagiełło, 2016; Jagiełło, Gałka, 2016; Jagiełło, } \\
\text { Wołek, 2017; Kliucininkas, Matulevicius, Martuzevicius, 2012; Połom, } \\
\text { 2015b; Tica et al., 2011; Wołek, Wyszomirski, } 2013\end{array}$ \\
\hline & vehicle market & $\begin{array}{l}\text { Kołoś, Taczanowski, 2018; Połom, Turżański, 2011; Połom, 2015a; } \\
\text { Połom, 2015b; Połom, Turżański, Bartłomiejczyk, 2015; Połom, 2016; }\end{array}$ \\
\hline \multirow{4}{*}{ Technological aspects } & alternative power sources & $\begin{array}{l}\text { Bartłomiejczyk, Połom, 2011; Bartłomiejczyk, Połom, 2013; Połom, } \\
\text { Bartłomiejczyk, 2011; Połom, 2015b; Wołek, Wyszomirski, 2013; } \\
\text { Zalewska, 2017. }\end{array}$ \\
\hline & catenary and power system & $\begin{array}{l}\text { Bartłomiejczyk, Połom, Staroński, 2013; Bartłomiejczyk, 2016; } \\
\text { Bartłomiejczyk, Mirchevski, 2014; Hamacek et. al. 2014; Sopov, } \\
\text { Biryukov, Vorfolomeyev, 2006; }\end{array}$ \\
\hline & depot and workshops & Jarzmik, 2008; Połom, 2015b; \\
\hline & vehicles & $\begin{array}{l}\text { Bartłomiejczyk et al., 2012; Bartłomiejczyk, 2016; Bartłomiejczyk, } \\
\text { Mirchevski, 2014; Borowik, Cywiński, 2016; Brazis, Latkovskis, } \\
\text { Grigans, 2010; Dyr, 2013; Gładysz et al., 2016; Hamacek et. al. 2014, } \\
\text { Molecki, 2018; Połom, Bartłomiejczyk, 2012; Połom, Bartłomiejczyk, } \\
\text { 2015; Połom, 2015b; Wołek, Wyszomirski, } 2013\end{array}$ \\
\hline \multirow{3}{*}{ Transport policies } & $\begin{array}{l}\text { comparison of operation } \\
\text { with other means of public } \\
\text { transport }\end{array}$ & $\begin{array}{l}\text { Costa, Fernandes, 2012; Falvo, 2012; Klucininkas, Matulevicius, 2009; } \\
\text { Połom, 2015b; Tica et al., 2011; }\end{array}$ \\
\hline & impact on the environment & $\begin{array}{l}\text { Klucininkas, Matulevicius, 2009; Połom, 2015b; Rasiński, 2018; Tica } \\
\text { et al., 2011; }\end{array}$ \\
\hline & $\begin{array}{l}\text { organization of trolleybus } \\
\text { transport }\end{array}$ & $\begin{array}{l}\text { Anisiewicz, 2004; Bartłomiejczyk, Połom, 2013; Bartłomiejczyk, } \\
\text { Połom, Goliszek, 2016; Bogusławski, 2006; Borowik, Cywiński, 2016; } \\
\text { Cywiński, Brud, 2017; Falvo, 2012; Khorovitch, 2004; Molecki, 2011; } \\
\text { Molecki, 2018; Molecki, 2013; Połom, 2014; Połom, 2015b; Rulaff, } \\
\text { 2013; Tarnawski, Zalewska, 2018; Tica et al., 2011;TTuszyński, 2015; } \\
\text { Wołek, 2012; Wołek, 2013; Wołek, Wyszomirski, 2013; Wyszomirski, } \\
\text { Hebel, } 2013\end{array}$ \\
\hline
\end{tabular}

Source: Own elaboration.

\section{Characteristics of the trends in the functioning of trolleybus transport in Europe and in the world in the 21st century}

In the 21st century, trolleybuses began to gain popularity again, especially in cities that already had infrastructure. The aforementioned policy of counteracting climate change drew the attention of local governments to the often neglected trolleybus systems, which in many cases were to be ultimately liquidated at the expense of buses. Thanks to the structural measures of the European Union, a significant part of the existing trolleybus systems has been revitalized and several new ones have been put into operation. Changes in the functioning of trolleybus transport in Europe and in the world can be divided according to the impact factors illustrated in tab. 2. 
Tab. 2. Factors of changes in the assessment of trolleybus transport.

\begin{tabular}{|l|l|}
\hline \multicolumn{1}{|c|}{ Group of factors: } & \multicolumn{1}{c|}{ Detailed: } \\
\hline Economic & $\begin{array}{l}\text { - development of the market of trolleybus producers (increased competitiveness), } \\
\text { - subsidies for the purchase of low- and zero-emission vehicles, } \\
\text { - improving the effectiveness of trolleybus operators (reducing technical departments, e.g. through } \\
\text { outsourcing services). }\end{array}$ \\
\hline Political & $\begin{array}{l}\text { - the impact of climate change on the awarding of low-emission and zero-emission vehicles, } \\
\text { - introducing a policy at the level of countries and the European Union regarding the development } \\
\text { of electromobility and the complete exclusion of emission vehicles in cities, } \\
\text { - use of trolleybus transport to increase ecological awareness (a showcase of the pro-ecological city). }\end{array}$ \\
\hline Technological & $\begin{array}{l}\text { - changing the drives to more energy-efficient (energy recovery during braking), } \\
\text { - development of combustion unit technology (partial independence from the overhead network), } \\
\text { - development of battery technology (partial independence from the overhead network and } \\
\text { maintaining the advantages of a fully electric vehicle), } \\
\text { - development of fully low-floor vehicles, } \\
\text { - vehicle size development - bi-articulated trolleybuses, } \\
\text { - modernization of solutions in the field of overhead traction not limiting the speed of trolleybuses. }\end{array}$ \\
\hline
\end{tabular}

Source: Own elaboration.

\section{Spatial changes in trolleybus transport in Poland after 2004}

An indispensable element of the development of trolleybus transport systems in Poland after 2004 were spatial changes related to the construction of new traction infrastructure (new parts of the traction network) and the launch of new connections. Creating new connections in trolleybus transport was associated with the use of the newly built catenary, but also thanks to alternative power sources installed in trolleybuses.

In fig. 1-2 illustrates the changes taking place in 2004-2018 in Gdynia. The main infrastructure investments include new sections of the catenary in the south-western part of the city, serving the districts of Dąbrowa and Dąbrówka, as well as two short branches, the first from the main cross-city artery (Morska Street) to the Fast Urban Rail (PKP SKM) stop in the Grabówek district, and the second in as a street loop (ul. 3 Maja). The remaining new sections were serviced by trolleybuses equipped with batteries.
The new routes made it possible to service parts of Gdynia and Sopot that had not been serviced by trolleybuses so far. These were, in particular, connections to the Fikakowo estate in the Wielki Kack district, to Kościuszko Square and the Southern Pier (Molo Południowe) in the city center, as well as to the border of Sopot and Gdańsk at the Ergo Arena sports hall (Jagiełło, Gałka, 2017). In the following years, along with the deliveries of the ordered trolleybuses, new connections will be launched, in 2019 a new line 34 will be opened to the Demptowo district. The route of line 27 will also be modified to serve the office center at Łużycka str. and sports facilities at Sportowa str. using power from batteries. It is also planned to partially service the bus line 181 , connecting Gdynia and Sopot via Karwiny by trolleybuses. In 2020, the launch of another new trolleybus line 32 is planned, which will replace the 170 bus line serving the northern part of the city (Połom, 2015b). 


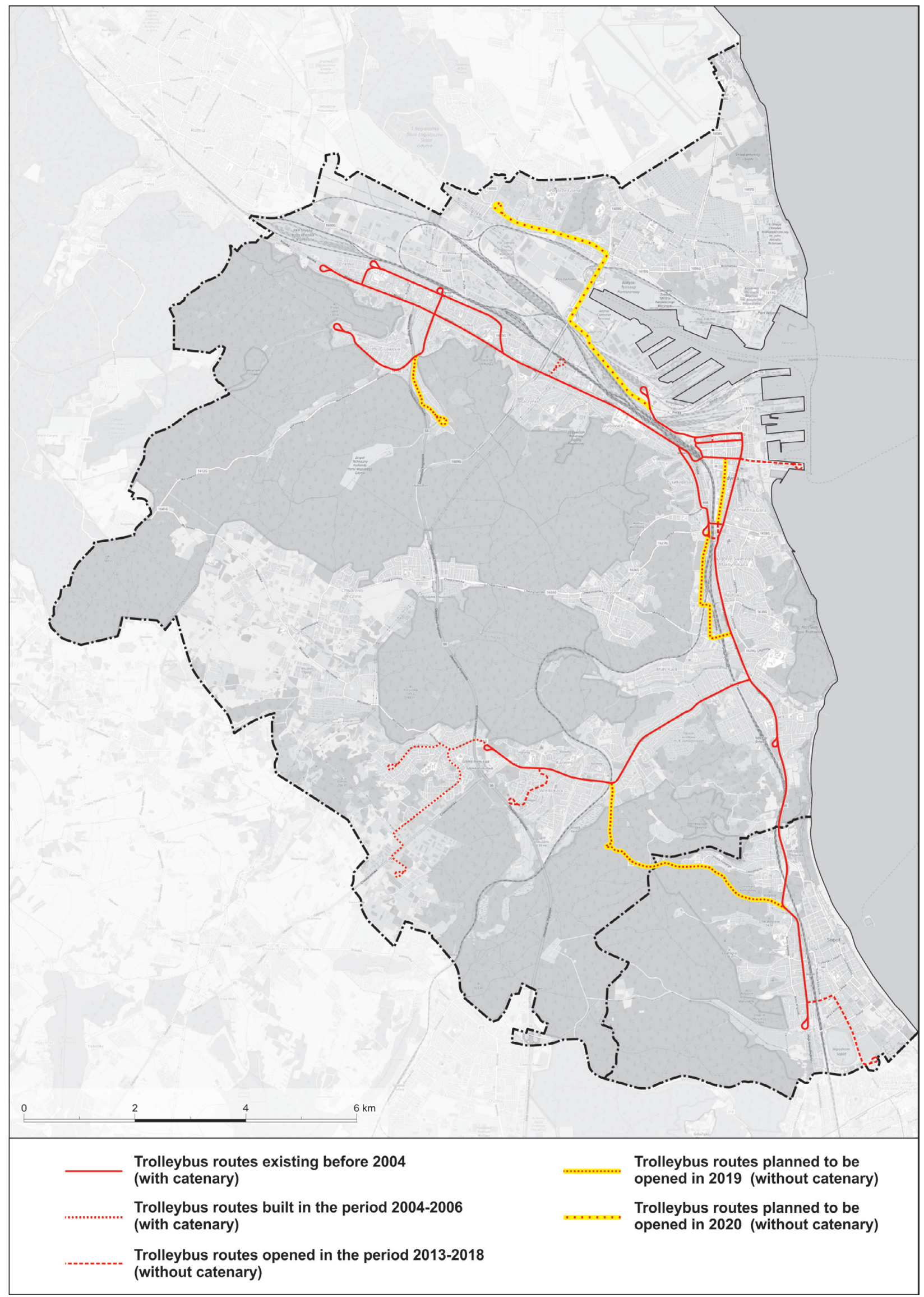

Fig. 1. Spatial development of trolleybus routes in Gdynia and Sopot.

Source: Own elaboration. 


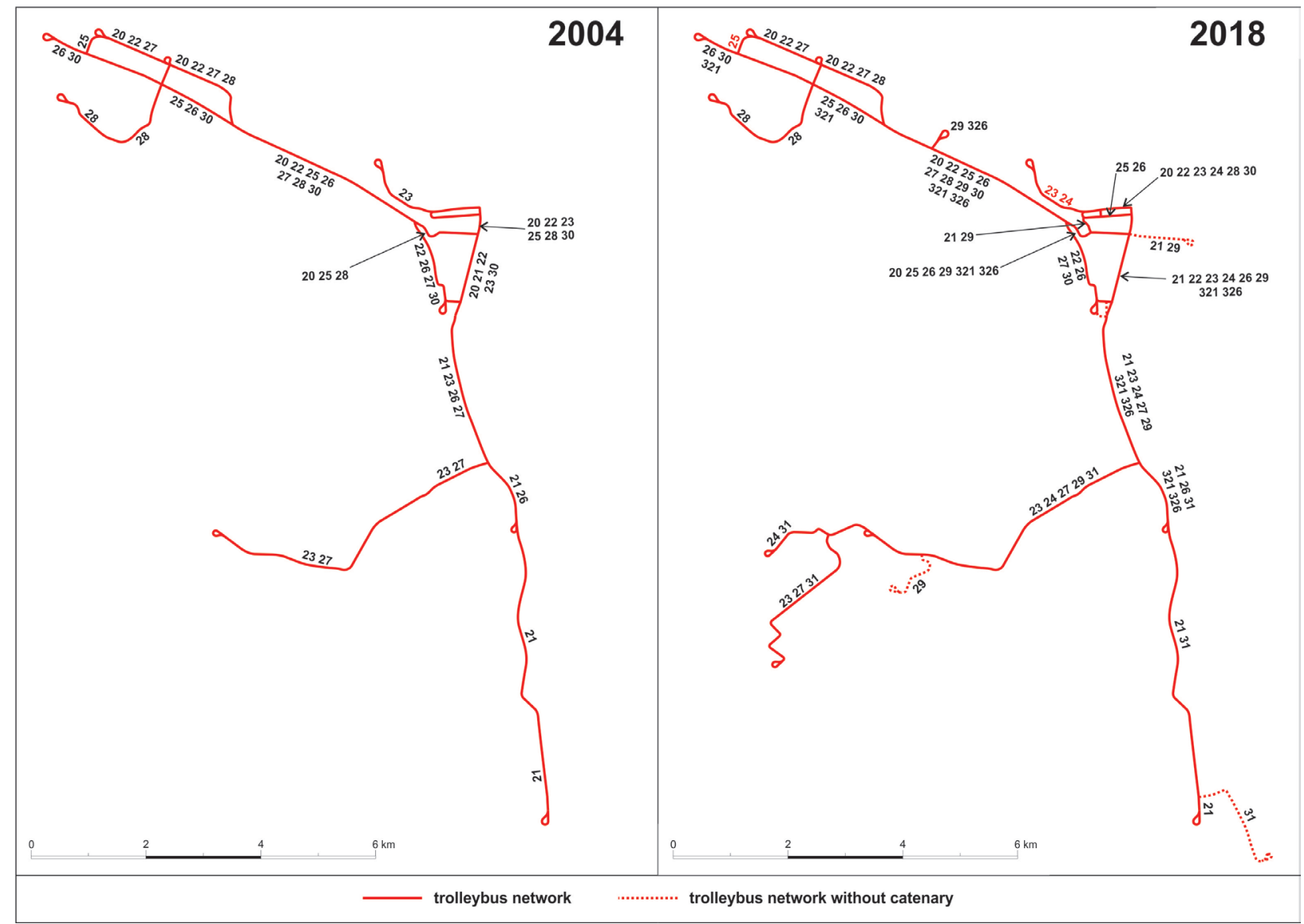

Fig. 2. Comparison of the trolleybus connection network in Gdynia and Sopot in 2004 and 2018.

Source: Own elaboration.

In fig. 3-4 presents changes in the network of trolleybus connections and presents the new traction infrastructure in Lublin. The years 2004-2018 abounded in numerous investments co-financed from European Union funds. The traction network has doubled. There were new routes that led to the Czuby district. The number of routes towards Węglin and to Czechów was developed. Connections with Abramowice and Majdanek were extended. The routes in Śródmieście were also compacted. Figure 4 illustrates a significant increase in trolleybus lines in Lublin between 2004 and 2018. In 2004, there were eight trolleybus lines $(150-153,155-156,158,160)$. Over the following years, three more were launched $(154,157,159)$. Two bus lines were also electrified. The route number 10 was changed to 160 , and the bus route number 19 began to be serviced by trolleybuses without renumbering. On some routes, alternative power sources installed in vehicles (power generators and batteries) were used. At the end of the analyzed period, other trolleybus routes were also under construction (Połom, 2015b; Tarnawski, Zalewska, 2018). 


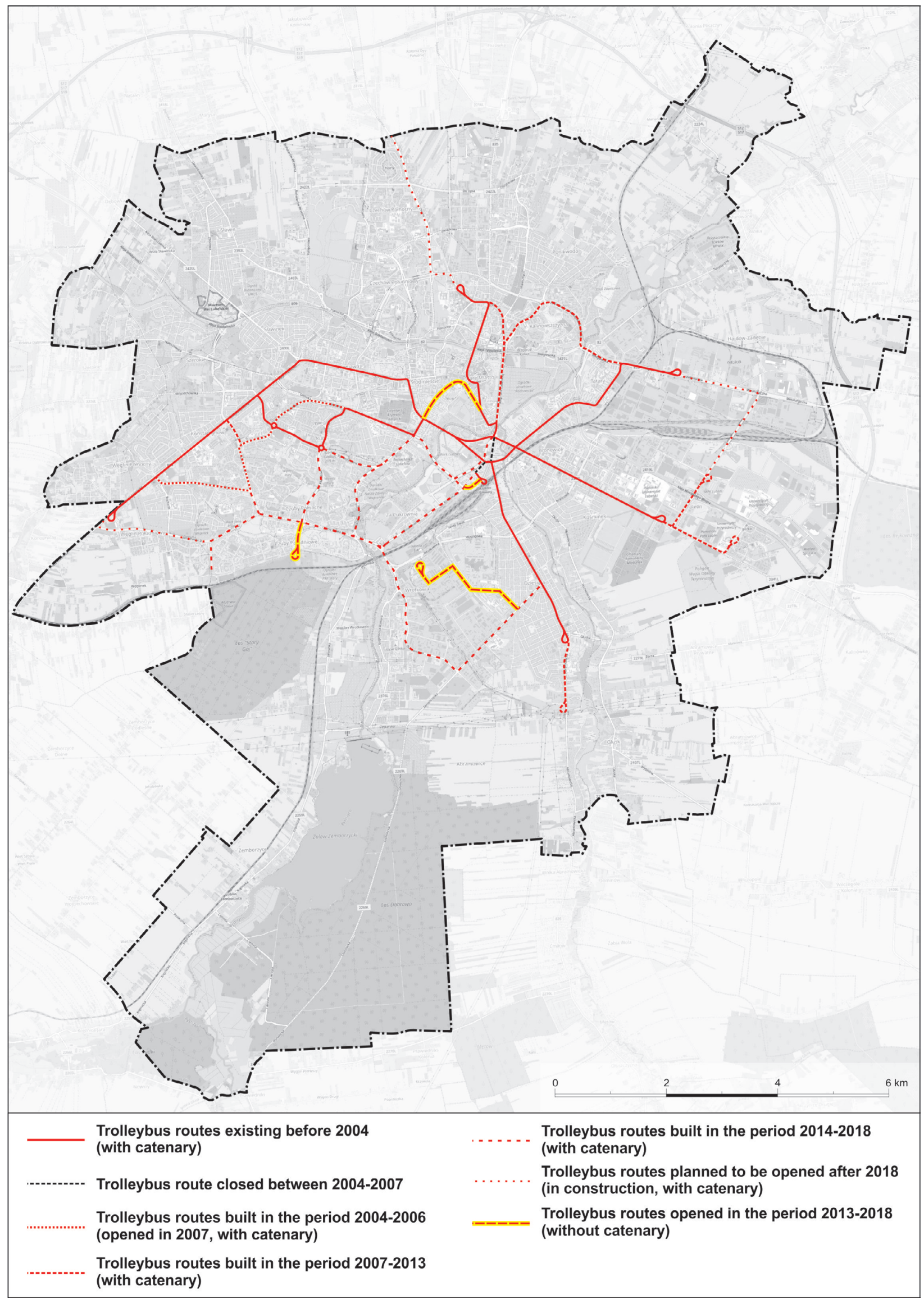

Fig. 3. Spatial development of trolleybus routes in Lublin.

Source: Own elaboration. 


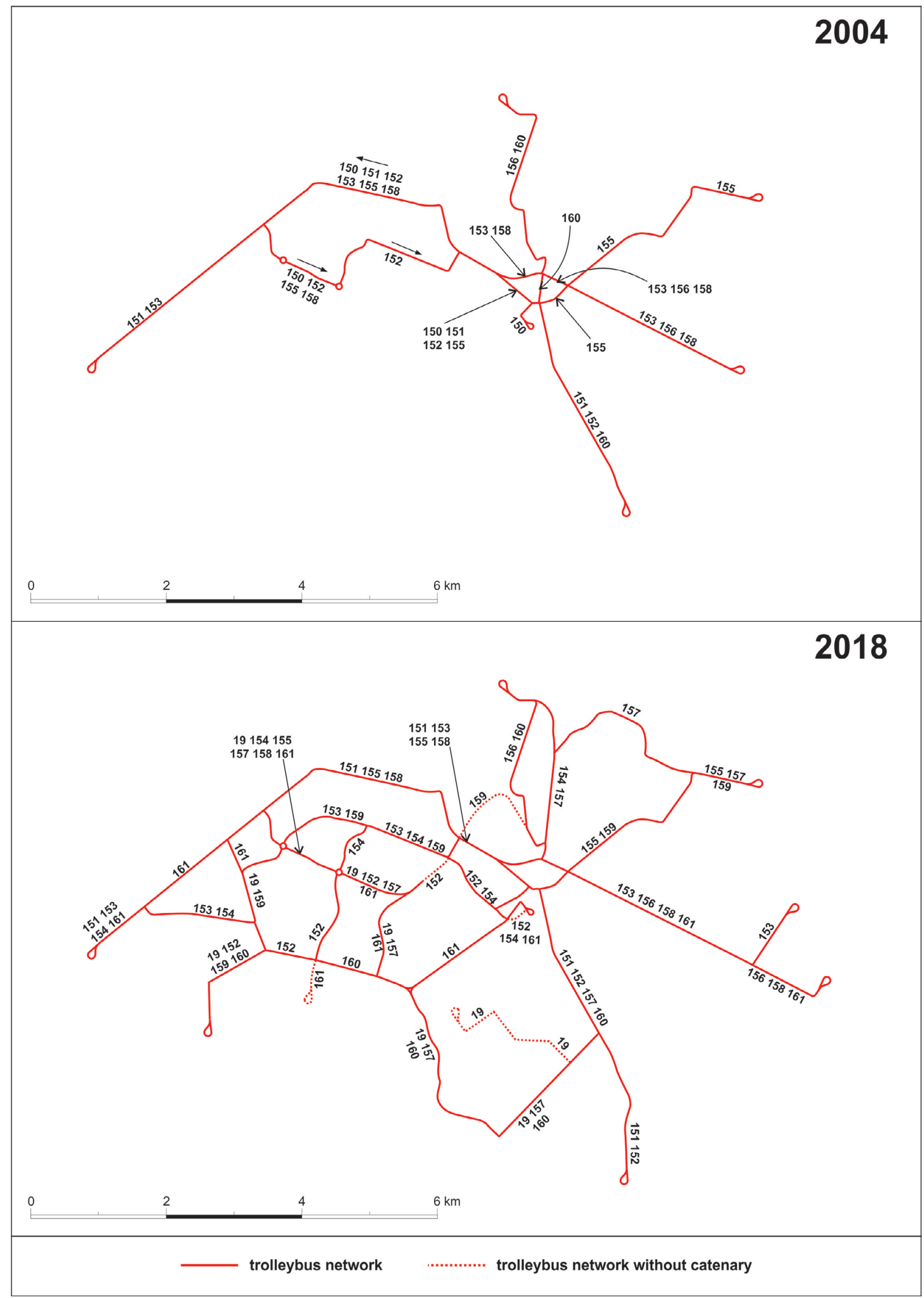

Fig. 4. Comparison of the trolleybus connection network in Lublin in 2004 and 2018.

Source: Own elaboration. 
As in the case of the two previous trolleybus systems, also in Tychy, in the period 2004-2018 there were spatial changes. However, they mainly concerned connections. During this period, no new infrastructure was built in Tychy. At the end of 2018, i.e. the analyzed period, the only new route was under construction. It was a connection constituting an extension from the loop in the Paprocany district towards the south to the $Z$ and $Z 1$ estates. In the ana- lyzed period, the number of trolleybus lines marked with letters increased to six. The only new line marked as $\mathrm{F}$ ran from the Paprocany district to the center, which it circled in the form of a street loop. The remaining A-E lines ran on different routes connecting the railway station. In 2019, a new trolleybus line is planned to be launched, partly using battery power (Borowik, Cywiński, 2017; Cywiński, Brud, 2017; Dyr, 2013; Połom, 2015).

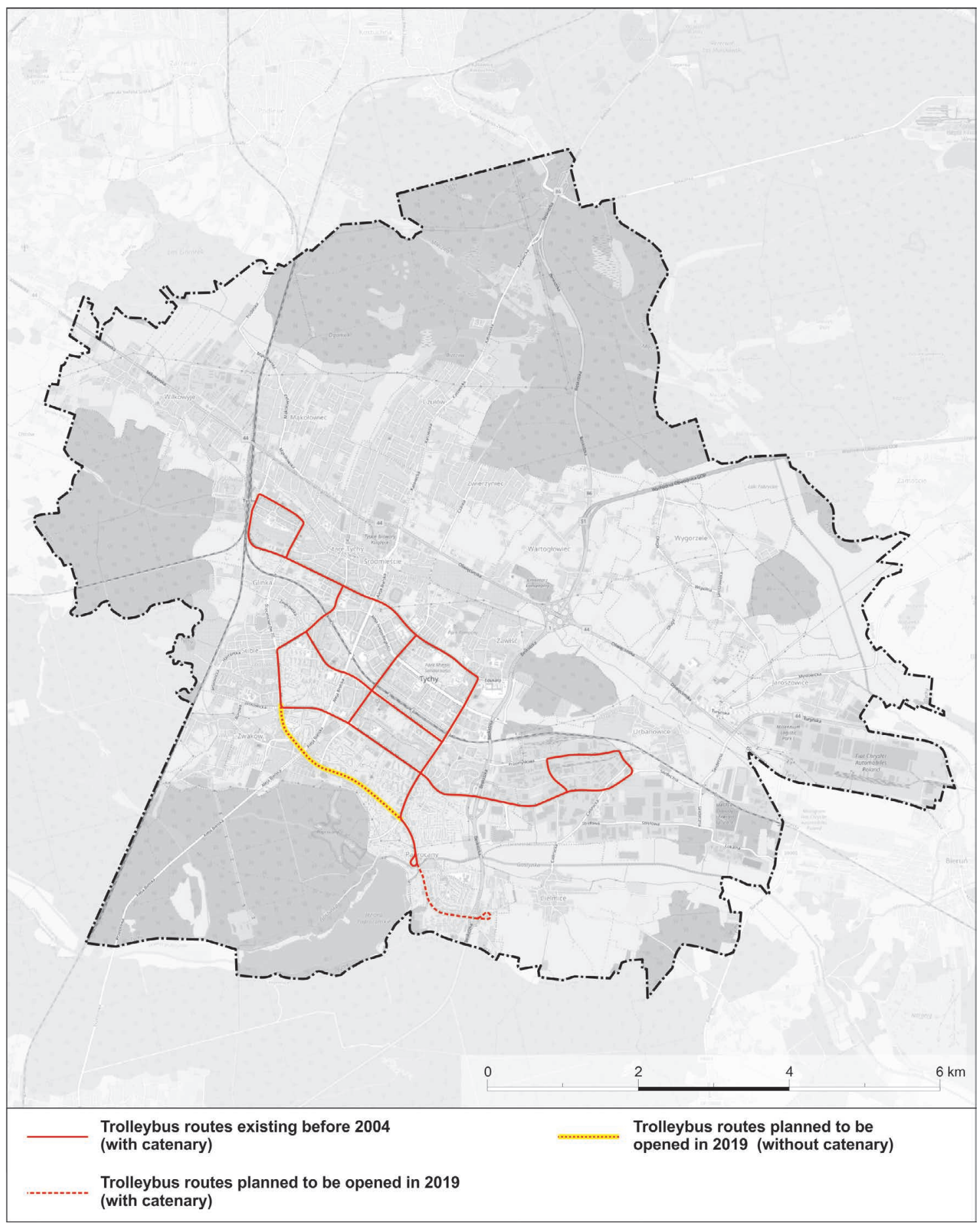

Fig. 5. Spatial development of routes operated by trolleybuses in Tychy.

Source: Own elaboration. 


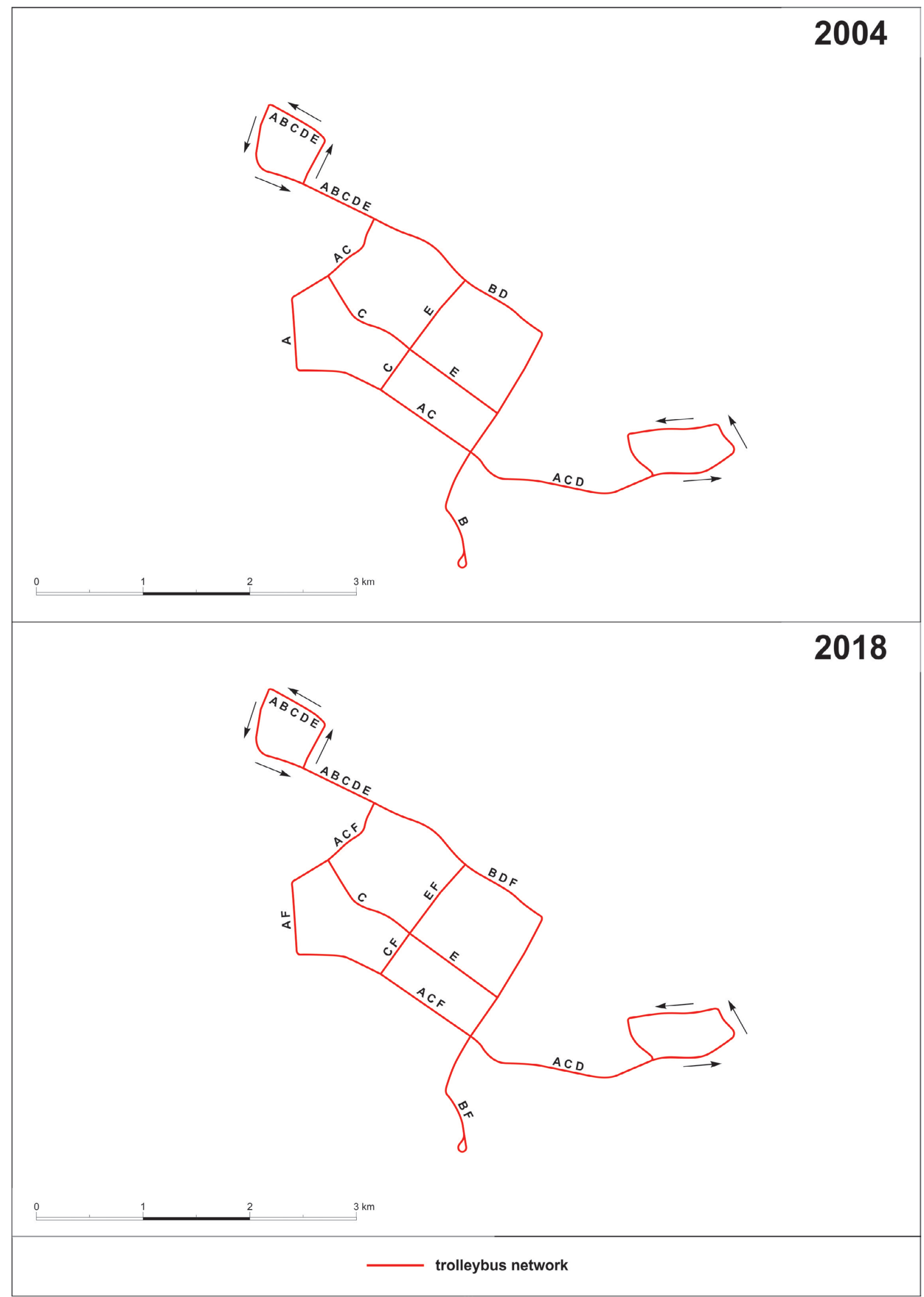

Fig. 6. Comparison of the trolleybus connection network in Tychy in 2004 and 2018.

Source: Own elaboration. 


\section{The phenomenon of diffusion of innovation in Polish trolleybus transport systems}

In recent years, trolleybus transport has undergone a number of changes in all three existing systems in Poland. Particularly noteworthy is the phenomenon of diffusion of technological innovations, which significantly influenced the contemporary image of trolleybuses. The model examples include the conversion of buses with diesel engines purchased from the secondary market in Gdynia. At the beginning of the 21st century, the market of producers of new low-floor trolleybuses in Europe was very hermetic, and the costs of vehicles significantly exceeded the investment possibilities of Polish carriers. Moreover, the reconstruction needs of the trolleybus fleet parks were significant. In 2003, i.e. a year before the analysis undertaken in this article, the disproportion between the quality of trolleybus and bus communication in Gdynia was significant. Therefore, the concept of building trolleybuses based on the bodies of low-floor buses from the secondary market appeared. Such a solution was not a novelty in Gdynia because it was already used, for example, in the 1970s and 1980s, with brand new or worn-out high-floor bodies being built at that time. A similar solution was also used in Lublin. In the years 20042014, 36 trolleybuses were built in Gdynia in this way, including 28 trolleybuses based on Mercedes Benz O405N bodies, 2 using Mercedes Benz O530 and 3 Solaris Urbino 12 bodies. Until the end of 2018, a dozen of the youngest of them remained in service although the converted vehicles had an estimated life expectancy of seven years (Bartłomiejczyk et al., 2012, Połom, Bartłomiejczyk, 2015). Based on the same idea, a batch of 3 vehicles was made in Tychy in 2006-2008, but with the use of brand new Solaris bodies. In the same period, in Lublin, using a similar idea, a batch of 3 high-floor vehicles was made, then 3 Solaris trolleybuses, 1 trolleybus based on the MAZ body and another 3 Jelcz low-entry trolleybuses. The appearance of a significant number of low-floor vehicles in the trolleybus transport offer influenced the perception of this means of transport.

The second example of innovation in trolleybus transport, which became popular in all three trolleybus networks in Poland, was the introduction of modern solutions in the field of catenary, which would not limit the speed of trolleybuses. The first prototype solution was used in 1998 in Gdynia, where tests of the radio-controlled network switch began. Positive experiences with the operation of this device and then with other network solutions have led to a com- plete transformation of the perception of trolleybuses as very slow and even slower vehicles on turns and crossings. At the end of the second decade of the 21st century, such solutions became widely used in all three Polish trolleybus systems (Połom, 2015b).

One of the features that influenced the negative perception of trolleybuses was the dependence on the catenary. In the event of congestion, breakdown, road collision, street renovation, etc., trolleybuses had to be replaced by buses. Maintaining an additional reserve in the form of replacement vehicles worsened the economic balance. The solution to this problem was provided by alternative power sources for trolleybuses. Initially, these were diesel combustion units mounted directly on the vehicle. Such a solution began to be used in a batch of 20 Solaris trolleybuses in Lublin. In such a case, however, it is difficult to defend the argument about the lack of emission of trolleybuses at the place of operation and their positive impact on the environment. Another route was sought in Gdynia, where an attempt was made to equip brand new and converted trolleybuses with batteries. At that time, it was still an unpopular alternative to power generators and burdened with a certain level of risk. The first trolleybuses with batteries (in nickel-cadmium technology) appeared in Gdynia in 2010-2011. These were 28 Solaris vehicles purchased as part of a project co-financed by the European Union. The capacity of the batteries at that time made it possible to treat them as an alternative source in the event of a detour, renovation of a section of the route or other unforeseen situations. Good operating experience and constant development of battery technologies, mainly by increasing their capacity while reducing their size, and especially weight, allowed for the development of this idea. Another new trolleybuses in Gdynia were ordered equipped with increasingly larger and more effective battery power sources, and the other carriers from Lublin and Tychy went in the same direction. At the end of 2018 , over $60 \%$ of trolleybuses operating in Gdynia were equipped with various battery power sources. It is worth noting that Gdynia has become a precursor to the use of battery-powered trolleybuses in constant line traffic, which is currently also happening in other Polish cities (Bartłomiejczyk, Połom, 2011; Połom, 2015).

Similar experiences concerned technical facilities. The first new trolleybus depot was built in Gdynia. It was put into operation in 2007. Based on the Gdynia experience, including the negative ones, a new trolleybus depot in Lublin was designed and built in 2015 (Bartłomiejczyk, Połom, 2013; Bartłomiejczyk, Goliszek, Połom, 2016). 


\section{Development of trolleybus production in Poland}

The development of trolleybus transport in the first and second decade of the 21st century was also associated with the functioning of a large and significant producer of trolleybuses on the domestic market. From the beginning of the 20th century, the production of trolleybuses in various configurations and with the participation of various partners was developed by the Solaris Bus \& Coach company from Bolechowo. In the years 2000-2018, it produced a total of 1,210 trolleybuses for various recipients, mainly foreign, in particular in Bulgaria, the Czech Republic, Latvia and Germany. The first trolleybuses of this brand were produced in 2000-2001 and delivered to Gdynia and Riga. In the following years, the Solaris brand was developed and trolleybuses of various sizes $(12,15$ and 18 meters) were produced and in cooperation with various suppliers of drives and components. Figure 7 shows the connections of the Polish manufacturer with propulsion manufacturers, which shows that they were four out of the seven main companies in the passenger electric transport industry. The next illustration shows the chronological relations between Solaris and the propulsion suppliers (fig. 8).

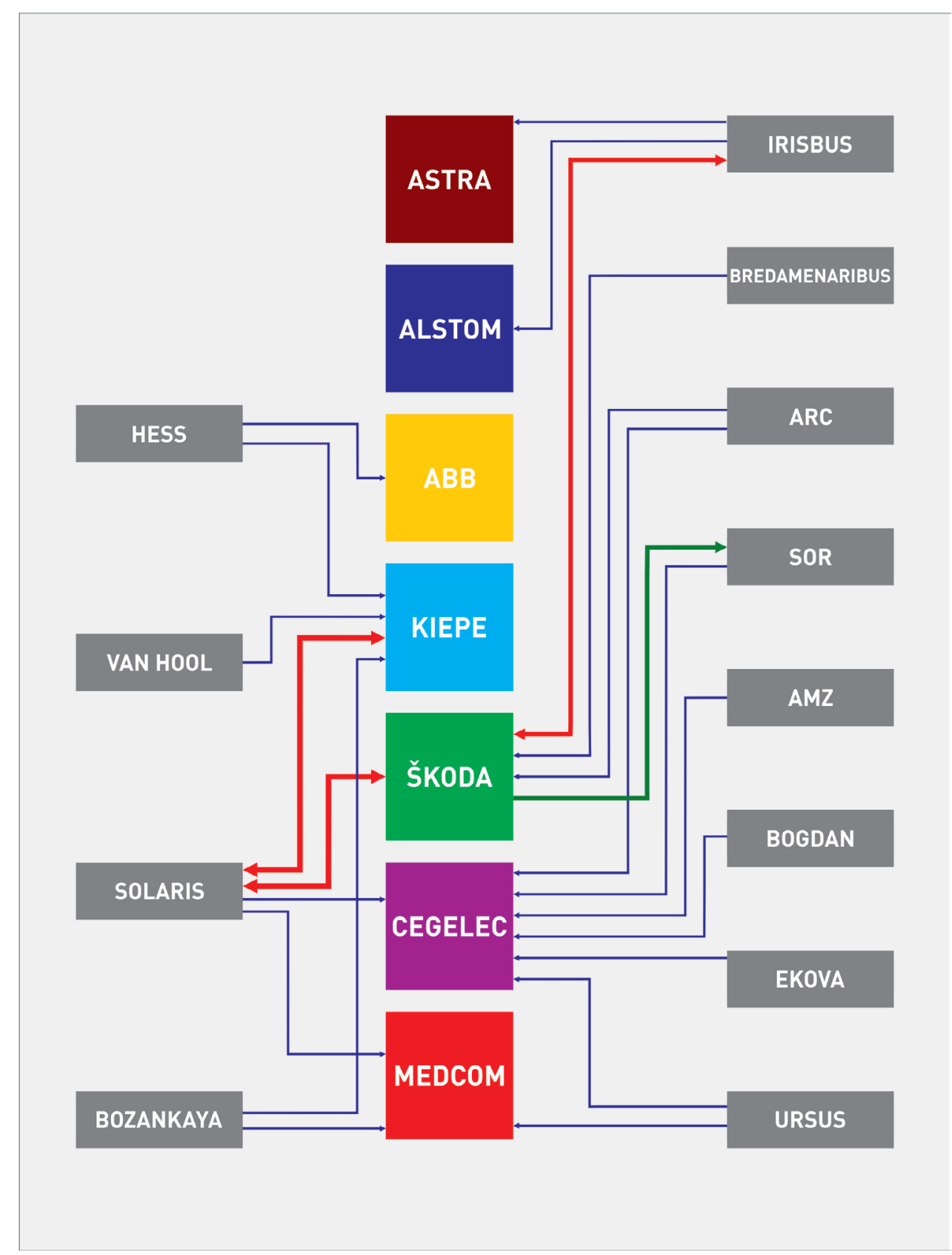

Fig. 7. Connections between trolleybus producers and producers of trolleybus drives (in the middle of the diagram). Source: Own elaboration. 


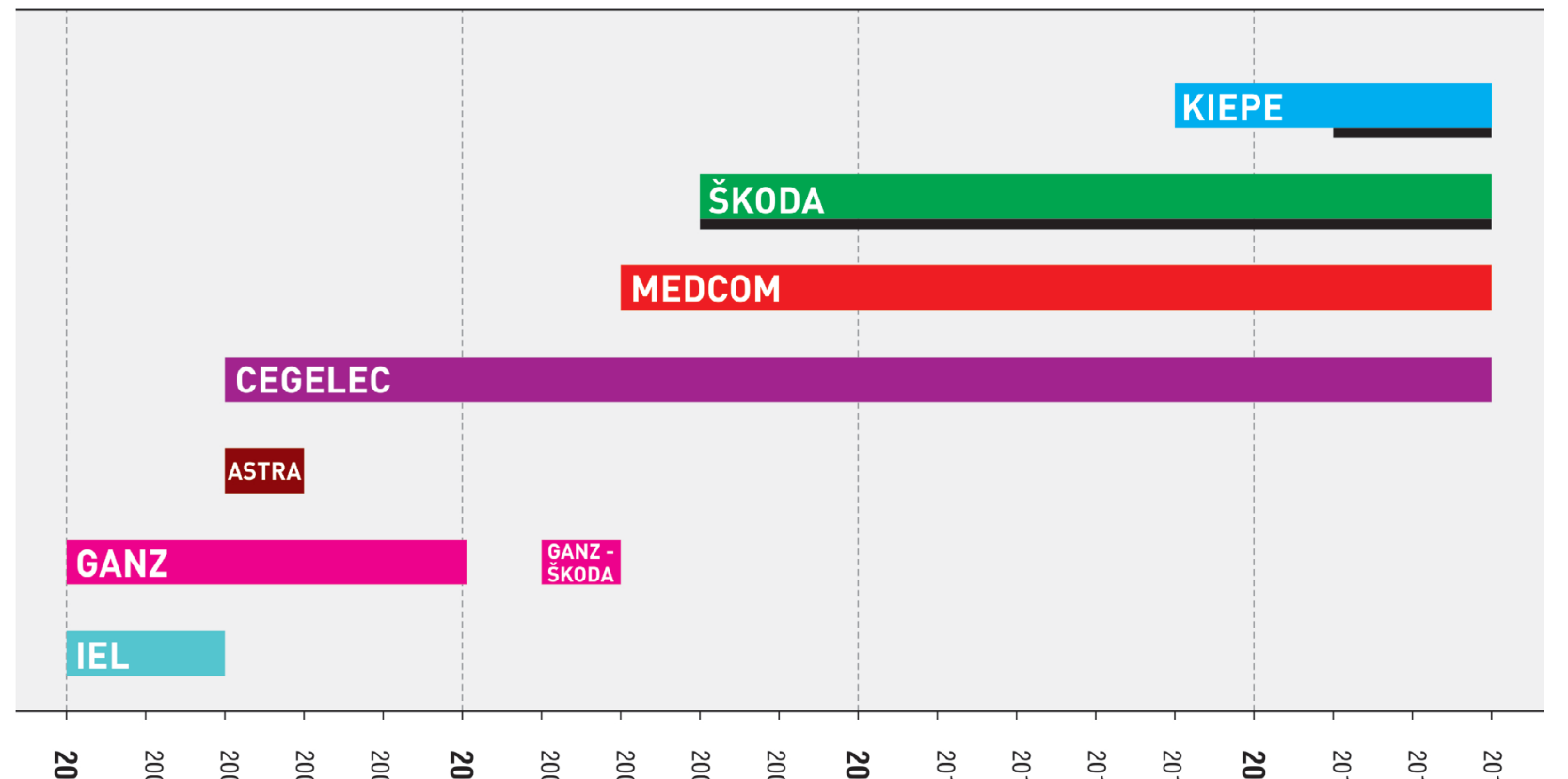

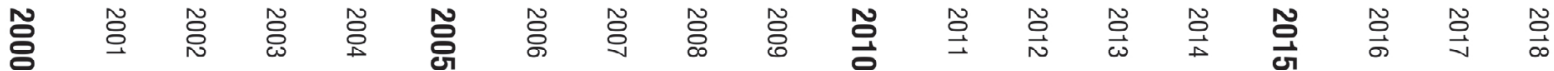

IEL - Institute of Electrical Engineering, Poland; GANZ/Ganz-Škoda, Hungary; Astra, Romania; Cegelec, Czechia; Medcom, Škoda Czechia; Kiepe, Germany. Black line - time when the trolleybuses were purchased as final product of that company too, not as Solaris.

Fig. 8. Chronology of cooperation between Solaris and suppliers of trolleybus drives.

Source: Own elaboration.

In the years 2004-2018, new Solaris trolleybuses were purchased in all three Polish trolleybus systems, and a local supplier, the Ursus company, also appeared in Lublin. Initially, in cooperation with the Ukrainian producer of buses and trolleybuses, Bogdan Motors, 38 low-floor trolleybuses with a length of 12 meters were delivered to Lublin and equipped with batteries allowing for go up to $10 \mathrm{~km}$ without power supply from the catenary. Then Ursus started producing vehicles based on its own bodies (previ- ously developed by another Polish company AMZ from Kutno). This type of articulated trolleybuses were also delivered to Lublin in the following years. In 2019, Ursus, due to financial problems, completely ceased the production of buses and trolleybuses, thus failing to complete the last order from Lublin for 10 trolleybuses with a length of 12 meters. Tables 3 and 4 show purchases of trolleybuses in 2004-2018 in Poland (Połom, Turżański, 2011; Połom, Turżański, Bartłomiejczyk, 2015; Połom, 2015a; Połom, 2016).

Tab. 3. Number of trolleybuses delivered to Polish cities in 2004-2018.

\begin{tabular}{|c|c|c|c|c|c|c|c|c|c|c|c|c|c|c|c|c|}
\hline City/year & $\mathbf{2 0 0 4}$ & $\mathbf{2 0 0 5}$ & $\mathbf{2 0 0 6}$ & $\mathbf{2 0 0 7}$ & $\mathbf{2 0 0 8}$ & $\mathbf{2 0 0 9}$ & $\mathbf{2 0 1 0}$ & $\mathbf{2 0 1 1}$ & $\mathbf{2 0 1 2}$ & $\mathbf{2 0 1 3}$ & $\mathbf{2 0 1 4}$ & $\mathbf{2 0 1 5}$ & $\mathbf{2 0 1 6}$ & $\mathbf{2 0 1 7}$ & $\mathbf{2 0 1 8}$ & sum: \\
\hline Gdynia & 3 & 8 & 14 & 6 & 6 & 6 & 17 & 10 & 7 & 3 & 2 & & 4 & & 18 & 104 \\
\hline Lublin & & 3 & & & & 5 & & 18 & 15 & 25 & 24 & 21 & & & 15 & 126 \\
\hline Tychy & 1 & 1 & 2 & & 1 & & & & 1 & 14 & & & & & 2 & 22 \\
\hline sum: & 4 & 12 & 16 & 6 & 7 & 11 & 17 & 28 & 23 & 42 & 26 & 21 & 4 & & 35 & 252 \\
\hline
\end{tabular}

Source: Own elaboration. 
Tab. 4. Trolleybuses put into operation in 2004-2018 in Polish cities, broken down by type.

\begin{tabular}{|c|c|c|c|c|}
\hline $\begin{array}{l}\text { City } \\
\text { (sum) }\end{array}$ & Brand & $\begin{array}{l}\text { Number } \\
\text { (pcs.) }\end{array}$ & $\begin{array}{l}\text { Years of } \\
\text { production }\end{array}$ & Optional accessories \\
\hline \multirow{9}{*}{ Gdynia } & Solaris Trollino 12AC & 15 & 2004-2008 & \\
\hline & Mercedes Benz O405NE & 22 & 2004-2009 & reclaimed drive, vehicle converted from buses \\
\hline & Mercedes Benz O405NI & 1 & 2008 & impulse drive, vehicle converted from the bus \\
\hline & Mercedes Benz O405NAC & 5 & $2009-2010$ & $\begin{array}{l}\text { low capacity nickel-cadmium batteries, } \\
\text { asynchronous drive, vehicle converted from buses }\end{array}$ \\
\hline & Mercedes Benz O530AC & 2 & 2012 & $\begin{array}{l}\text { low capacity nickel-cadmium batteries, } \\
\text { asynchronous drive, vehicle converted from buses }\end{array}$ \\
\hline & Solaris Urbino 12AC & 3 & $2012-2013$ & $\begin{array}{l}\text { low capacity nickel-cadmium batteries, } \\
\text { asynchronous drive, vehicle converted from buses }\end{array}$ \\
\hline & Solaris Trollino $12 \mathrm{M}$ & 38 & 2009-2016 & nickel-cadmium batteries \\
\hline & Solaris Trollino 12M (IV gen.) & 13 & 2018 & lithium-ion batteries \\
\hline & Solaris Trollino 18M (IV gen.) & 5 & 2018 & lithium-ion batteries \\
\hline \multirow{10}{*}{ Lublin } & Jelcz 120MT & 3 & 2005 & vehicles built on the basis of new bodies \\
\hline & Solaris Trollino 12M & 3 & 2009 & vehicles built on the basis of new bodies \\
\hline & Solaris Trollino 12AC & 1 & 2009 & \\
\hline & MAZ 203T & 1 & 2009 & vehicles built on the basis of new bodies \\
\hline & Jelcz 121ME & 3 & 2011 & vehicles built on the basis of new bodies \\
\hline & Solaris Trollino 12S & 30 & 2011-2012 & \\
\hline & Solaris Trollino $12 \mathrm{M}$ & 20 & 2013 & additional diesel drive \\
\hline & Ursus T70116 & 38 & 2013-2015 & lithium-ion batteries \\
\hline & Solaris Trollino $18 \mathrm{M}$ & 12 & 2014 & lithium-ion batteries \\
\hline & Ursus CS18LFT & 15 & 2018 & lithium-ion batteries \\
\hline \multirow{4}{*}{ Tychy } & Solaris Trollino $12 \mathrm{AC}$ & 2 & $2004-2005$ & \\
\hline & Solaris Trollino 12DCR & 3 & $2006-2008$ & vehicles built on the basis of new bodies \\
\hline & Solaris Trollino $12 \mathrm{M}$ & 15 & $2012-2013$ & nickel-cadmium batteries \\
\hline & Solaris Trollino 12M (IV gen.) & 2 & 2018 & lithium-ion batteries \\
\hline
\end{tabular}

Source: Own elaboration.

The analysis shows that in the years 2004-2018, 252 trolleybuses were delivered to Polish cities, including 219 brand new and previously not operated. The largest number of new trolleybuses was purchased by Lublin - 126. Over the years, trolleybuses were equipped with additional power sources, initially with a diesel generator or traction batteries with a smaller capacity, then with high-capacity lithium-ion batteries allowing for line operation on selected parts without the overhead network (Gładysz et al., 2016) .

\section{Summary}

The article analyzes the state and dynamics of changes in Polish trolleybus systems in the years 2004-2018. The study contains information on the status of the organization, rolling stock and infrastructure of trolleybus networks in Gdynia (with Sopot), Lublin and Tychy. The considerations were carried out in relation to literature sources concerning the situation in Europe and in the world. The analysis shows that trolleybus transport plays an important role in the above-mentioned urban centers and this role increased in the analyzed period. In order to modernize trolleybus transport, it was mainly financed by the European Union. Trolleybus transport is in line with the assumptions adopted by the European Union in the field of reducing emissions of pollutants into the environment, so the funding opportunities were successfully used. In the years 2004-2018, 252 trolleybuses were put into operation in Polish trolleybus transport, including 219 new ones. Most of them were vehicles manufactured in Poland, as one of the producers became an important player on the market of bus and trolleybus producers in Europe, supplying many vehicles for export.

The development of technologies in the field of auxiliary drives, in particular batteries and traction network, made it possible to eliminate the disproportion between bus and trolleybus transport. The auxiliary power supply was successfully used both in emergency and regular traffic, extending the transport offer by trolleybuses, e.g. in areas with a lower population density, where the construction of the traction network would be unprofitable. 
In all analyzed centers there were spatial changes both in the length of the traction network and the number of connections. In particular, most new sections of the catenary were put into operation in Lublin.

Trolleybus transport has regained importance due to unfavorable climate changes and the need to adapt various spheres of the economy to the reduced emission of pollutants. The analysis shows that there are still no scientific and expert studies on the impact of trolleybus transport on the environment and comparative studies with other means of urban transport, in particular buses. Reliable scientific studies would allow to refute the myths unfavorable for trolleybuses and perhaps make the plans of some cities related to the introduction of electric buses more realistic.

\section{Acknowledgements}

The article has been written on the basis of research project "Socio-economic, environmental and technical conditions of electrical transport development and operation in Poland". The project has been financed from the National Science Centre - UMO2016/23/D/HS4/03085.

\section{References}

Anisiewicz R., 2004, Wybrane aspekty funkcjonowania komunikacji trolejbusowej w Gdyni, Prace Komisji Geografii Komunikacji PTG, t. X, 367-381.

Bartłomiejczyk M., 2016, Praktyczna aplikacja In Motion Charging w Gdyni: trolejbusy w obsłudze linii autobusowych, TTS Technika Transportu Szynowego, 23(7-8), 58-64.

Bartłomiejczyk M., Dombrowski J., Połom M., Wyszomirski O., 2012, Konwersja autobusu z silnikiem diesla na trolejbus, Zakład Poligrafii FRUG, Gdańsk, pp. 84.

Bartłomiejczyk M., Goliszek S., Połom M., 2016, Innowacyjne rozwiązania szansą rozwoju systemów transportu trolejbusowego na przykładzie Gdyni i Lublina, Acta Scientarum Polonorum Administratio Locorum, 15(4), 7-25.

Bartłomiejczyk M., Mirchevski S., 2014, Reducing of energy consumption in public transport-Results of experimental exploitation of super capacitor energy bank in Gdynia trolleybus system, Power Electronics and Motion Control Conference and Exposition (PEMC), 2014 16th International, 94-101.

Bartłomiejczyk M., Połom M., 2011, Trolejbusy z bateryjnym źródłem zasilania-doświadczenia eksploatacyjne i koncepcja liniowego zastosowania w Gdyni, TTS Technika Transportu Szynowego, 18, 76-80.

Bartłomiejczyk M., Połom M., 2013, Perspektywa wykorzystania napędu alternatywnego w lubelskiej komunikacji trolejbusowej. Cz. 1, TTS Technika Transportu Szynowego, 20, 36-38.
Bartłomiejczyk M., Połom M., Staroński, K., 2013, Próbna eksploatacja zasobnika superkondensatorowego w gdyńskiej sieci trolejbusowej, TTS Technika Transportu Szynowego, 20(6), 40-44.

Bogusławski J., 2006, Gdynia rozbudowuje sieć trolejbusową, Transport Miejski i Regionalny, 1, 27-31

Borowik L., CywińskiA., 2016, Modernization of a trolleybus line system in Tychy as an example of eco-efficient initiative towards a sustainable transport system, Journal of Cleaner Production, 117, 188-198.

Brazis, V., Latkovskis L., Grigans L., 2010, Simulation of trolleybus traction induction drive with supercapacitor energy storage system, Latvian Journal of Physics and Technical Sciences, 47(5), 33-47.

Costa Á., Fernandes R., 2012, Urban public transport in Europe: Technology diffusion and market organisation, Transportation Research Part A: Policy and Practice, 2(46), 269-284.

Cywiński A., Brud Z., 2017, Tyskie trolejbusy-elektromobilość od roku 1982, Komunikacja Publiczna, 2, 55-59.

Dyr T., 2013, Inwestycje taborowe Tyskich Linii Trolejbusowych, Autobusy: technika, eksploatacja, systemy transportowe, 14, 26-32.

Gładysz A., Czech P., Łazarz B., Matyja T., Juzek M., 2016, Uwarunkowania techniczne dotyczące pojazdów wykorzystywanych $\mathrm{w}$ regularnym przewozie osób na przykładzie tyskich linii trolejbusowych, Autobusy: technika, eksploatacja, systemy transportowe, 17(6), 16881693.

Grzelec K., Wyszomirski O., 2010, Eksploatacyjne, ekonomiczne i społeczne uwarunkowania rozwoju komunikacji trolejbusowej na przykładzie Gdyni, Technika Transportu Szynowego, 5-6, 55-59.

Falvo M.C., 2012, An environmental sustainable transport system: A trolley-buses Line for Cosenza city, Power Electronics, Electrical Drives, Automation and Motion (SPEEDAM), 2012 International Symposium on, 1479-1485. Hamacek Š., Bartłomiejczyk M., Hrbáč R., Mišák S., Stýskala V., 2014, Energy recovery effectiveness in trolleybus transport, Electic Power Systems Research, 112, 1-11.

Hebel K., 2014, Zmiany preferencji i zachowań transportowych mieszkańców Gdyni w latach 1996-2013, Transport Miejski i Regionalny, 4, 10-14.

Jagiełło A., 2016, Analiza SWOT gdyńskich trolejbusów, Zeszyty Naukowe Uniwersytetu Gdańskiego. Ekonomika Transportu i Logistyka, 61, 115-136.

Jagiełło A., Gałka P., 2017, Impact of changes in organization of trolleybus line no. 29 in Gdynia on passengers' travel behaviour, Transport Economics and Logistics, 70, 109-117.

Jagiełło A., Wołek M., 2017, Preferencje pasażerów gdyńskiego transportu miejskiego w zakresie wzrostu dostępności przestrzennej usług poprzez wydłużenie trasy linii trolejbusowej, Studia Ekonomiczne, 332, 56-73. 
Jarzmik M., 2008, Aktualne wymagania inwestycyjne przy budowie nowej zajezdni komunikacji miejskiej - na przykładzie Przedsiębiorstwa Komunikacji Trolejbusowej Sp. z o.o. w Gdyni, Biuletyn Komunikacji Miejskiej, 99, 48-52.

Khorovitch B., 2004, The trolleybus in a modern city: stateof-the-art and future perspectives, Public Transport International, 53(4), 53-57.

Kliucininkas L., Matulevicius J., 2009, Comparative Analysis of Bus and Trolleybus Related GHGs Emissions and Costs in Lithuania, 5th International Vilnius Conference EURO Mini Conference "Knowledge-Based Technologies and OR Methodologies for Strategic Decisions of Sustainable Development" (KORSD-2009), 187-191.

Kliucininkas L., Matulevicius J., Martuzevicius D., 2012, The life cycle assessment of alternative fuel chains for urban buses and Trolleybuses, Journal of Environmental Management, 99, 98-103.

Kołoś A., Taczanowski J., 2018, Możliwości i dylematy rozwoju miejskiego transportu szynowego w Polsce, Prace Komisji Geografii Komunikacji PTG, 21(3), 31-44.

Kühne R., 2010, Electric buses - An energy efficient urban transportation means, Energy, 35, 4510-4513.

Mołecki A., 2011, Perspektywy dla komunikacji trolejbusowej, Autobusy: technika, eksploatacja, systemy transportowe, 12, 24-31.

Molecki A., 2018, Zasilanie liniowe w aspekcie rozwoju branży autobusów elektrycznych, Autobusy-Technika, Eksploatacja, Systemy Transportowe, 221(7-8), 28-32.

Molecki B., 2013, Nowa definicja trolejbusu w Prawie o Ruchu Drogowym, Autobusy: technika, eksploatacja, systemy transportowe, 14(5), 27.

Połom M., 2014, Koncepcja wzrostu znaczenia elektromobilności w transporcie zbiorowym Trójmiasta, Zeszyty Naukowe. Problemy Transportu i Logistyki, Uniwersytet Szczeciński, 27, 181-194.

Połom M., 2015a, Przestrzenne aspekty produkcji i eksportu autobusów w Polsce w latach 1989-2014, Prace Komisji Geografii Przemysłu Polskiego Towarzystwa Geograficznego, 1(29), 56-72.

Połom M., 2015b, Przemiany funkcjonowania komunikacji trolejbusowej w Polsce w latach 1989-2013, rozprawa doktorska, Uniwersytet Gdański.

Połom M., 2016, Produkcja i sprzedaż trolejbusów Škoda w latach 2004-2014, Autobusy: technika, eksploatacja, systemy transportowe, 17(12), 32-36.

Połom M., Bartłomiejczyk M., 2011, Alternatywne źródła zasilania w trolejbusach-przegląd rozwiązań stosowanych w miastach europejskich, TTS Technika Transportu Szynowego 18(3), 19-24.

Połom M., Bartłomiejczyk M., 2012, Odbudowa zabytkowego trolejbusu Skoda 9Tr w Gdyni, Autobusy: technika, eksploatacja, systemy transportowe, 13(1-2), 40-49.
Połom M., Bartłomiejczyk M., 2015, Ewolucja projektu konwersji autobusów niskopodłogowych na trolejbusy w Gdyni, Autobusy: technika, eksploatacja, systemy transportowe, 6, 28-32.

Połom M., Turżański B., 2011, Doświadczenia Solaris Bus \& Coach w produkcji trolejbusów. TTS Technika Transportu Szynowego, 18, 42-49.

Połom M., Turżański B., Bartłomiejczyk M., 2015, Produkcja i sprzedaż trolejbusów Solaris Trollino w latach 20112014, Autobusy: technika, eksploatacja, systemy transportowe, 16, 8-12.

Rasiński T., 2018, Trolejbus jako ekologiczny środek transportu miejskiego, Autobusy: technika, eksploatacja, systemy transportowe, 19(12), 213-216.

Rulaff M., 2013, Projekt Trolley jako przykład promowania ekologicznego transportu zbiorowego, Zeszyty Naukowe Politechniki Poznańskiej. Organizacja i Zarządzanie, 60, 89-96.

Sopov V.I., Biryukov V.V., Vorfolomeyev G.N., 2006, Increase of Efficiency of The Power Supply System of a Trolleybus, Strategic Technology, The 1st International Forum, 336-337.

Tarnawski R., Zalewska A., 2018, Rozwój elektromobilności w Lublinie, [w:] P. Maleszyk, M. Sagan (eds.) Lublin 2030-europejska metropolia?, 211-228.

Tica S., Filipić S., Živanović P., Bajčetić S., 2011, Development of trolleybus passenger transport subsystems in terms of sustanaible development and quality of life in cities, International Journal for Traffic and Engineering, 1(4), 196-205.

Tuszyński M., 2015, Rozwój proekologicznego transportu zbiorowego w Gdyni, Transport Miejski i Regionalny, 6, 28-32.

Wołek M., 2012, Projekt TROLLEY jako platforma współpracy środowisk transportowych w Europie ŚrodkowoWschodniej, Autobusy: technika, eksploatacja, systemy transportowe, 13(10), 16-18.

Wołek M., 2013, Transport trolejbusowy w kształtowaniu zrównoważonej mobilności miejskiej na przykładzie Gdyni, Autobusy: technika, eksploatacja, systemy transportowe, 14(7-8), 42-46.

Wołek M., 2014, Stan obecny i perspektywy rozwoju transportu trolejbusowego w Gdyni, Transport Miejski i Regionalny, 4, 20-25.

Wołek M., Wyszomirski O. (eds.), 2013, The Trolleybus as an Urban Means of Transport in the Light of the Trolley Project, Wydawnictwo Uniwersytetu Gdańskiego, Gdańsk.

Wyszomirski O., Hebel K., 2013, 70 lat trolejbusów w Gdyni, Autobusy: technika, eksploatacja, systemy transportowe, 14, 48-56.

Zalewska A., 2017, Napędy autonomiczne w trolejbusach na przykładzie miasta Lublin. Autobusy: technika, eksploatacja, systemy transportowe, 18(12), 1443-1449. 